\title{
COMPARATIVE FRUIT QUALITY PARAMETERS OF 'NINFA' APRICOT (PRUNUS ARMENIACA L.) GRAFTED ON TWO DIFFERENT ROOTSTOCKS IN A NEWLY ESTABLISHED ORGANIC ORCHARD
}

\author{
L.F. Pérez-Romero, F.T. Arroyo, C. Santamaría, M. Camacho and A. Daza* \\ Andalusian Institute of Agricultural and Fisheries Research and Training (IFAPA), "Las Torres-Tomejil" Centre, \\ Apdo. Oficial, 41200 Alcalá del Río (Sevilla), Spain
}

(Received: 12 November 2012; accepted: 15 January 2013)

\begin{abstract}
The fruit quality parameters of Prunus armeniaca L. cv 'Ninfa' grafted on 'Myrobalan 29C' (Prunus cerasifera Ehrh.) and 'Real Fino' apricot seedling (Prunus armeniaca L.) were analysed in an experimental orchard under organic management. The study was performed between 2010 and 2012 in the province of Seville (SW Spain). Colour, fruit and stone weights, firmness, soluble solid concentration, and acidity were measured for fruit quality evaluation. Trunk cross-sectional area, main branches, and fruit yield were also determined. In general, 'Myrobalan 29C' rootstock produced fruit slightly larger in size and with a bigger weight. By contrast, apricots on 'Myrobalan $29 \mathrm{C}$ ' had less firmness and a lower solid soluble concentration than on 'Real Fino'. There was little difference in the colour, acidity, and stone dry weights. Trees on 'Real Fino' had larger areas of trunk and branches but no significant differences were obtained in relation to fruit yields.
\end{abstract}

Keywords: tree growth, yield, organic agriculture, 'Myrobalan 29C', 'Real fino', soluble solids content

Apricot trees (Prunus armeniaca L.), originally from China and Central Asia where they have been cultivated since $2000 \mathrm{BC}$, are now a commercially important fruit in many countries of Europe, including Spain (Ruiz \& Egea, 2008; Gatti et al., 2009). Fruit quality is affected by cultivar (LEDBETTER et al., 1996; TriCON et al., 2009), soil characteristics (VAN LEEWEN et al., 2004; KHAn et al., 2011), climatic conditions (Gunduz et al., 2011), and agronomy (PÉrEZPAstor et al., 2007; Roussos et al., 2011). Rootstocks commonly used in orchards influence not only tree vigour and yield (EGEA et al., 2004; JIMÉNEZ et al., 2007), but also the quality attributes in fruit (DAZA et al., 2008; Hernández et al., 2010; Milosevic et al., 2011).

Quality and safety of food as well as the conservation of the natural environment are two aspects increasingly demanded in modern societies. Organic agriculture is a system that prevents the use of synthetic chemicals in crop protection and control of weeds, uses strategies with low environmental impact, and has been well regulated in Europe for years (EEC, 1991, revised with EC, 2007). However, organic fruit production is very low, perhaps because of the difficulty of an adequate control of pests and diseases (WEIBEL et al., 2007). Consequently, studies on the quality of organic fruit are still scarce. The richness of genotypes of apricot makes it an interesting species for low input systems, such as organic farming. 'Ninfa' is recommended as an interesting early apricot cultivar in relation to yield and fruit quality attributes (Lo BiANCO et al., 2010). The aim of the present work was to compare the standard fruit quality parameters of this cultivar grafted on two different rootstocks in a newly established orchard, organically managed.

\footnotetext{
* To whom correspondence should be addressed.

Phone: +34 671532842; fax: +34 955045625; e-mail: antonio.daza@juntadeandalucia.es
} 


\section{Materials and methods}

\subsection{Plant material and trial characteristics}

Prunus armeniaca L. cv 'Ninfa' grafted on 'Myrobalan 29C' (Prunus cerasifera Ehrh.) and 'Real Fino' apricot seedling ( $P$. armeniaca L.) was used in this work. All the trees were planted in January 2008 as bare root one year old, non-feathered, grafted onto both rootstocks. The study was carried out in the period 2010-2012 in an experimental organic orchard located at the IFAPA Centro "Las Torres-Tomejil" in the province of Seville in the

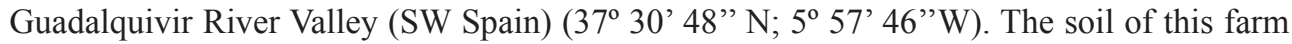
was classified as a Xerofluvent (SoIL SuRvey StafF, 1999). Fertilization was applied annually with animal manure at a dose of 4-5 $\mathrm{kg} \mathrm{m}^{-2}$; in addition, several cover greens, including beans and oat+vetch, were annually sown in November and buried in March. The orchard was irrigated during the dry season (approx. June-August) by gravity along two rows parallel to the line of trees. Each year, depending on climatic conditions, from 5 to 8 irrigations were applied (350 $0001 \mathrm{ha}^{-1}$ each). Land management consisted of reduced tillage. The planting framework was $5 \mathrm{~m} \times 4 \mathrm{~m}$ between and within the rows, respectively, and trees had a pruning training vessel, taking care that all pruned trees bear a similar width and height onto both rootstocks. The different pest and disease treatments were adjusted to regulations in organic farming (EC, 2007). The experiment was set up in a randomised block design with three replications, each containing 4 trees of each cultivar. The region has a Type $C$ Mediterranean climate, according to the Köppen classification (PeEL et al., 2007). The most relevant agroclimatic conditions registered in the zone during the time of the study are shown in Table 1.

Table 1. Agroclimatic conditions along the study

\begin{tabular}{lccc}
\hline Parameter & \multicolumn{3}{c}{ Year } \\
\cline { 2 - 4 } & (2009)-2010 & (2010)-2011 & $(2011)-2012$ \\
Chilling units (1 November to 15 February, hours below & 404 & 494 & 849 \\
$7^{\circ} \mathrm{C}$ ) & & & 287.8 \\
Rainy (September to August, mm) & 942.4 & 662.8 & 18.60 \\
Main air temperature (15 April to 15 May, $\left.{ }^{\circ} \mathrm{C}\right)$ & 18.43 & 18.81 & 60.35 \\
Main air humidity (15 April to 15 May, $\%)$ & 66.67 & 72.56 & \\
\hline
\end{tabular}

\subsection{Fruit analysis}

Fruit for analysis was harvested 64, 67, and 69 days after full bloom in 2010, 2011, and 2012, respectively. Twenty four fruits were collected from each of the four trees of each rootstock / replication, the fruits were picked at 1 to 2 meters in height and on each of the four cardinal points to avoid fruit position effect. Eighteen apricots were randomly taken from each batch and were processed for all the quality analysis. Size was determined using a digital slide gauge Mitutoyo CD-15CR (Mitutoyo America Corp., Kawasaki, Japan). Following the terminology proposed by CAILLAVET and SOUTY (1950), polar (ØР), suture (ØS), and equatorial (ØE) fruit diameters were measured and then transformed to the parameter denominated "size" defined as $(\varnothing \mathrm{P}+\varnothing \mathrm{S}+\varnothing \mathrm{E}) / 3$. Fruit weight was also evaluated. Fruit colour parameters $L^{*}, a^{*}$, and b* were measured with a Minolta colorimeter CR-300 (Minolta Co., Ltd., Osaka, 
Japan). Soluble solid concentration $\left({ }^{\circ}\right.$ Brix) was determined using an ATAGO PR-101 (ATAGO Co. Ltd., Tokyo, Japan) digital refractometer. Titratable acidity was determined on three juice samples (6 apricots each), diluted in distilled water, and microtitrated with $\mathrm{NaOH}$ $0.1 \mathrm{~N}$. The ripeness index was calculated as the ratio solid soluble concentration/acidity. Fruit firmness was tested with a penetrometer 53205 (TR di Turoni \& C. Snc, Forlì, Italy).

\subsection{Tree growth and yield}

Growth and vigour of the trees were evaluated in 2011 and 2012 in November at the end of the growing season by calculating the trunk cross-section area of the trunk (TCSA) $20 \mathrm{~cm}$ above the graft union (LEPSIS \& BLANKE, 2006). The cross-sectional areas of the main branches (MBCSA) emerging from trunk were also measured. Additionally, the rootstock crosssectional area (RCSA) $10 \mathrm{~cm}$ below the graft union was measured in 2012 . The production in 2012 ( kg per tree) was calculated taking into account the total fruit collected in all trees on each rootstock, tree replicates with 4 trees each.

\subsection{Statistical analysis}

Statistical analyses were performed using Statistix software version 9.0 (NH Analytical Software, Tallahassee, USA). Single analysis of variance was used to analyse all the experimental data. Results were expressed at the $\mathrm{P}<0.05$ level of significance.

\section{Results and discussion}

\subsection{Fruit size and weight}

With regard to fruit size, trees grafted on 'Myrobalan 29C' plum rootstock produced fruit slightly larger all the three years but only with a significant difference in 2012 (Table 2). The mean values did not show significant differences. Consequently with size, the fruit weights were also bigger on Myrobalan rootstock and with significant differences in 2010 and 2012. The fruit weight mean values also showed significant difference. An increase in both parameters on both rootstocks was observed from 2010 to 2012.

Table 2. Comparative fruit size and weight of Prunus armeniaca cv. 'Ninfa' grafted onto 'Myrobalan 29C' plum and 'Real Fino' apricot seedlings as rootstocks in an organically managed orchard

\begin{tabular}{lcccc}
\hline \multirow{2}{*}{ Year } & \multicolumn{2}{c}{ Size $(\mathrm{cm})$} & \multicolumn{2}{c}{ Weight $(\mathrm{g})$} \\
\cline { 2 - 5 } & Myr. 29C & Real Fino & Myr. 29C & Real Fino \\
\hline 2010 & $40.21 \mathrm{a}$ & $39.28 \mathrm{a}$ & $41.12 \mathrm{a}$ & $34.72 \mathrm{~b}$ \\
2011 & $43.34 \mathrm{a}$ & $42.91 \mathrm{a}$ & $50.37 \mathrm{a}$ & $48.43 \mathrm{a}$ \\
2012 & $50.30 \mathrm{a}$ & $47.70 \mathrm{~b}$ & $72.57 \mathrm{a}$ & $62.48 \mathrm{~b}$ \\
Mean & $44.62 \mathrm{a}$ & $43.30 \mathrm{a}$ & $54.69 \mathrm{a}$ & $48.54 \mathrm{~b}$ \\
\hline
\end{tabular}

For each parameter and year, values followed by the same letter were not statistically different $(\mathrm{P}<0.05)$ 


\subsection{Fruit colour}

Fruit colour is sometimes an important factor for its marketability, and may be related to its degree of maturity. Few significant differences in the three colour coordinates were observed in the three years of the study (Table 3). Given that the correct meaning of the colour-related data must be interpreted after knowing the colour change of each variety at the time of ripening (DAzA et al., 2012), the slightly lower $a^{*}$ and $b^{*}$ values of the fruit produced on 'Real Fino' seem to suggest that fruit were more colourful.

Table 3. Comparative a*, $\mathrm{b}^{*}$ and $\mathrm{L} *$ colour parameters of Prunus armeniaca cv. 'Ninfa' grafted onto 'Myrobalan 29C' plum and 'Real Fino' apricot seedlings as rootstocks in an organically managed orchard

\begin{tabular}{lcccccc}
\hline Year & \multicolumn{2}{c}{$\mathrm{a}^{*}$} & \multicolumn{2}{c}{$\mathrm{b}^{*}$} & \multicolumn{2}{c}{$\mathrm{L}^{*}$} \\
\cline { 2 - 6 } & Myr. 29C & Real Fino & Myr. 29C & Real Fino & Myr. 29C & Real Fino \\
\hline 2010 & $16.20 \mathrm{a}$ & $14.66 \mathrm{a}$ & $45.48 \mathrm{a}$ & $43.37 \mathrm{~b}$ & $61.88 \mathrm{~b}$ & $63.95 \mathrm{a}$ \\
2011 & $15.60 \mathrm{a}$ & $12.99 \mathrm{~b}$ & $42.17 \mathrm{a}$ & $40.96 \mathrm{a}$ & $64.59 \mathrm{a}$ & $63.29 \mathrm{a}$ \\
2012 & $15.07 \mathrm{a}$ & $16.01 \mathrm{a}$ & $45.91 \mathrm{a}$ & $45.79 \mathrm{a}$ & $65.83 \mathrm{a}$ & $65.52 \mathrm{a}$ \\
Mean & $15.62 \mathrm{a}$ & $14.55 \mathrm{a}$ & $44.51 \mathrm{a}$ & $43.37 \mathrm{a}$ & $64.10 \mathrm{a}$ & $64.25 \mathrm{a}$ \\
\hline
\end{tabular}

For each parameter and year, values followed by the same letter were not statistically different $(\mathrm{P}<0.05)$

\subsection{Soluble solids and acidity}

The concentration of total soluble solids and acidity were similar in the fruit on both rootstocks, with no significant differences in any year (Table 4). In relation to the maturity index, significant differences were only observed in 2010, with higher values in the fruit on 'Real Fino'.

Table 4. Comparative soluble solids, acidity and maturity index of Prunus armeniaca cv. 'Ninfa' grafted onto

'Myrobalan 29C' plum and 'Real Fino' apricot seedlings as rootstocks in an organically managed orchard

\begin{tabular}{lcccccc}
\hline Year & \multicolumn{2}{c}{ Soluble solids $\left({ }^{\circ}\right.$ Brix $)$} & \multicolumn{2}{c}{ Acidity $(\mathrm{g}$ malic acid/100 ml) } & \multicolumn{2}{c}{ Maturity index } \\
\cline { 2 - 6 } & Myr. 29C & Real Fino & Myr. 29C & Real Fino & Myr. 29C & Real Fino \\
\hline 2010 & $13.05 \mathrm{a}$ & $13.48 \mathrm{a}$ & $2.71 \mathrm{a}$ & $2.22 \mathrm{a}$ & $4.81 \mathrm{~b}$ & $6.07 \mathrm{a}$ \\
2011 & $9.75 \mathrm{a}$ & $10.08 \mathrm{a}$ & $2.15 \mathrm{a}$ & $2.31 \mathrm{a}$ & $4.53 \mathrm{a}$ & $4.36 \mathrm{a}$ \\
2012 & $10.11 \mathrm{a}$ & $10.45 \mathrm{a}$ & $1.65 \mathrm{a}$ & $1.78 \mathrm{a}$ & $6.13 \mathrm{a}$ & $5.87 \mathrm{a}$ \\
Mean & $10.97 \mathrm{a}$ & $11.33 \mathrm{a}$ & $2.17 \mathrm{a}$ & $2.10 \mathrm{a}$ & $5.05 \mathrm{a}$ & $5.40 \mathrm{a}$ \\
\hline
\end{tabular}

For each parameter and year, values followed by the same letter were not statistically different $(\mathrm{P}<0.05)$

\subsection{Fruit firmness and stone dry weight}

Fruit always had a higher firmness when produced on 'Real Fino' apricot rootstock, showing significant differences in 2010, 2011, and in the mean values of the three years (Table 5). No relevant differences were observed with respect to stone weights, being slightly lower in the fruit on 'Real Fino' apricot. 
Table 5. Comparative firmness and stone dry weight of Prunus armeniaca cv. 'Ninfa' grafted onto 'Myrobalan 29C' plum and 'Real Fino' apricot seedlings as rootstocks in an organically managed orchard

\begin{tabular}{lcccc}
\hline \multirow{2}{*}{ Year } & \multicolumn{2}{c}{ Firmness $\left(\mathrm{kg} \mathrm{cm}^{-2}\right)$} & \multicolumn{2}{c}{ Stone weight $(\mathrm{g})$} \\
\cline { 2 - 5 } & Myr. 29C & Real Fino & Myr. 29C & Real Fino \\
\hline 2010 & $0.84 \mathrm{~b}$ & $2.16 \mathrm{a}$ & $1.71 \mathrm{a}$ & $1.56 \mathrm{~b}$ \\
2011 & $1.70 \mathrm{~b}$ & $2.38 \mathrm{a}$ & $1.83 \mathrm{a}$ & $1.77 \mathrm{a}$ \\
2012 & $1.35 \mathrm{a}$ & $1.68 \mathrm{a}$ & $2.24 \mathrm{a}$ & $2.13 \mathrm{a}$ \\
Mean & $1.29 \mathrm{~b}$ & $2.07 \mathrm{a}$ & $1.93 \mathrm{a}$ & $1.82 \mathrm{a}$ \\
\hline
\end{tabular}

For each parameter and year, values followed by the same letter were not statistically different $(\mathrm{P}<0.05)$

\subsection{Tree growth and yield}

The values of cross-sectional areas of the variety trunks (TCSA) and the main branches emerging from it (MBCSA) were higher in all cases for trees on 'Real Fino' rootstock, but with significant differences only in MBCSA and not in TCSA (Table 6). In 2012 the crosssectional areas of the rootstocks (RCSA) $10 \mathrm{~cm}$ below the graft union were also measured. The ratio RCSA / TCSA shows a more uniform bonding in terms of diameter between 'Ninfa' - 'Real Fino' than between 'Ninfa' - 'Myrobalan 29C'.

Table 6. Comparative trunk and main branches cross-sectional areas and fruit yield of Prunus armeniaca cv. 'Ninfa' grafted onto 'Myrobalan 29C' plum and 'Real Fino' apricot seedlings as rootstocks in an organically managed orchard

\begin{tabular}{|c|c|c|c|c|c|c|}
\hline \multirow[t]{2}{*}{ Rootstock } & \multicolumn{2}{|c|}{$\operatorname{TCSA}\left(\mathrm{cm}^{2}\right)$} & \multicolumn{2}{|c|}{$\operatorname{MBCSA}\left(\mathrm{cm}^{2}\right)$} & \multirow{2}{*}{$\frac{\text { RCSA / TCSA }}{2012}$} & \multirow{2}{*}{$\begin{array}{c}\text { Yield }(\mathrm{kg} / \text { tree }) \\
2012\end{array}$} \\
\hline & 2011 & 2012 & 2011 & 2012 & & \\
\hline Real Fino & $156.47 \mathrm{a}$ & $199.93 a$ & $65.96 \mathrm{a}$ & $86.23 a$ & $0.94 b$ & $20.55 a$ \\
\hline Myr. 29C & $126.29 a$ & $162.75 \mathrm{a}$ & $41.54 b$ & $57.03 b$ & $1.61 \mathrm{a}$ & $23.95 \mathrm{a}$ \\
\hline
\end{tabular}

TCSA: trunk cross sectional area of variety; MBCSA: main branches cross sectional area; RCSA: rootstock crosssectional area. In a column, for each parameter and year different letters indicate significant differences $(\mathrm{P}<0.05)$

\subsection{Discussion}

In southern Spain the most common rootstocks for apricot cultivation are apricot seedlings ('Real Fino' and 'Canino' cultivars), plums ('Pollizos de Murcia' and 'Myrobalans'), and peach Nemaguard (HERNÁNDEZ et al., 2010; JuAN ORERO, personal communication), among which the apricot has the highest affinity with a larger number of cultivars. Only a few studies on apricot organic farming have been carried out by the moment (LECCESE et al., 2010). The early ripening and good yield characteristics of the cultivar 'Ninfa' (SotTiLE et al., 2006; Lo BIANCO et al., 2010) suggest that its cultivation may be of interest in areas suitable for an early fruit production, such as Andalusia. This study compared tree growth and the standard fruit quality parameters of 'Ninfa' apricots produced on the rootstocks 'Myrobalan 29C' and 'Real Fino' in a newly established organic orchard.

In general, a more vigorous growth was observed on 'Real Fino' rootstock. Moreover, in grafted plants a uniform development of trunk rootstock and scion, as occurred with 
'Ninfa' - 'Real Fino', is another factor favouring a good vascular functionality of the tree as a whole (FELIPE, 1989). However, fruit yield was similar on both rootstocks.

Probably the colour in apricot is less relevant than in other fruits, such as apple or plum. Anyway, the results showed minimal differences in the fruit colour on the two rootstocks. A more important parameter in terms of quality is the amount of soluble solids, a key for early varieties usually with lower values. Although no significant differences were observed, always slightly higher values were obtained in fruit produced on 'Real Fino' apricot. Good fruit firmness ensures proper handling. In fruit showing a similar maturity index apricots produced on 'Real Fino' were statistically firmer than on 'Myrobalan 29C'. Although the differences were not relevant, apricots on 'Myrobalan 29C' were always slightly bigger and had more weight. This may be of value in a cultivar as 'Ninfa' that has a medium-low size. In a previous study of the behaviour of cultivar 'Ninfa' grafted onto different rootstocks, performed in Sicily in a conventionally managed orchard (SoTTILE et al., 2006), when grafted on 'Myrobalan 29 C', yield and fruit weight were lower than those obtained in the present work. Given that our study was conducted under organic management, usually with lower yields than conventional (DE PonTI et al., 2011), the comparison of these yield values with those obtained in this work suggest preliminary good yield and fruit quality of cultivar 'Ninfa' on both rootstocks used in this organically managed orchard.

\section{Conclusions}

A similar fruit yield of the cultivar 'Ninfa' was obtained on both rootstocks, 'Myrobalan 29C' and 'Real Fino'. Although the fruit from 'Myrobalan 29C' was slightly higher in size and bigger in weight, its firmness and solid soluble concentration were also lower. The results obtained in terms of yield, fruit quality, and the better cultivar-rootstock affinity observed for 'Real Fino' prompted us to think that this latter is more appropriate than 'Myrobalan 29C' as a rootstock for this early-ripeness apricot in the conditions used: organic farming in a clay loam soil in southern Spain.

We are grateful to R. Cabezas and M. Andra for technical assistance. Founding for this research was provided by the IFAPA (Project TRANSFORMA of Organic Farming EI.TRAT.TRA2010.17).

\section{References}

Caillavet, H. \& Souty, J. (1950): Monographie des principales variétés de pêches (Monograph of the main varieties of peaches.) ITEA, 37, 18-26.

Daza, A., García Galavís, P.A., Grande, M .J. \& Santamaría, C. (2008): Fruit quality parameters of 'Pioneer' Japanese plums produced on eight different rootstocks. Sci. Hort., 118, 206-211.

Daza, A., Camacho, M., Galindo, I., Arroyo, F.T., Casanova, L. \& Santamaría, C. (2012): Comparative fruit quality parameters of several Japanese plum varieties in two newly established orchards, organic and conventionally managed. Int. J. Food Sci. Technol., 47, 341-349.

De Ponti, T., Rijk, B. \& Van Ittersum, M.K. (2011): The crop yield gap between organic and conventional agriculture. Agric. Syst., 108, 1-9.

EEC (1991): Council Regulation No. 2092/91 of 24 June 1991 on organic production of agricultural products and foodstuffs. Off. J. Eur. Communities L 198 (22 July), 1-15.

EC (2007): Council Regulation No. 834/2007 of June 2007 on organic production and repealing Regulation. Off. J. Eur. Communities L 189 (20 July), 1-23. 
Egea, J., Ruíz, D. \& Martínez-Gómez, P. (2004): Influence of rootstocks on the productive behaviour of 'Orange Red' apricot under Mediterranean conditions. Fruits, 59, 367-373.

Felipe, A. J. (1989): Patrones para frutales de pepita y hueso. (Rootstocks for pome and stone fruit.) Técnicas Europeas, S.A., Barcelona, Spain, 181 pages.

Gatti, E., Defilippi, B.G., Predieri, S. \& Infante, R. (2009): Apricot (Prunus armeniaca L.) quality and breeding perspectives. J. Food Agric. Environ., 7, 573-580.

Gunduz, O., Cehyan, V. \& Bayramoglu, Z. (2011): Influence of climatic factors on apricot (Prunus armeniaca L.) yield in the Malatya province of Turkey. Asian J. Agric. Sci., 3, 150-155.

Hernández, F., Pinochet, J., Moreno, M.A., Martínez, J.J. \& Legua, P. (2010): Performance of Prunus rootstocks for apricot in Mediterranean conditions. Sci. Hort., 124, 354-359.

Jiménez, S., Pinochet, J., Gogorcena, Y., Betrán, J. \& Moreno, M.A. (2007): Influence of different vigour cherry rootstocks on leaves and shoots mineral composition. Sci. Hort., 112, 73-79.

Khan, A. S., Naseer, M., Malik, A.U., Basra, S.M.A., Khalid, M.S., Khalid, S., Amin, M., Saleem, B.A., Rajwana, I.A.\& UD DIN. (2011): Location, soil and tree nutrient status influence the quality of 'Kinnow' mandarin. Int. J. Agric. Biol., 13, 498-504.

Leccese, A., Bartolini, S., Viti, R. \& Pirazzini, P. (2010): Fruit quality performance of organic apricots at harvest and after storage from different environmental conditions. Acta Hort., 873, 165-172.

Ledbetter, C.A., Gómez, E., Burgos, L. \& Peterson, S. (1996): Evaluation of fruit quality of apricot cultivars and selections. J. Tree Fruit Prod., 1, 73-86.

Lepsis, J. \& Blanke, M.M. (2006): The trunk cross-section area as a basis for fruit yield modelling in intensive apple orchards. Acta Hort., 707, 231-235.

Lo Bianco, R., Farina, V., Indelicato, S.G., Filizzola, F. \& Agozzino, P. (2010): Fruit physical, chemical and aromatic attributes of early, intermediate and late apricot cultivars. J. Sci. Fd Agric. 90, 1008-1019.

Milosevic, T., Milosevic, N. \& Glisic, I. (2011): Influence of stock on the early tree growth, yield and fruit quality traits of apricot (Prunus armeniaca L.). Tarim Bilim. Derg., 17, 167-176.

Peel, M.C., Finlayson, B.L., \& McMahon, T.A. (2007): Updated world map of the Köppen-Geiger climate classification. Hydrol. Earth Syst. Sci., 11, 1633-1644.

Pérez-Pastor, A., Ruiz-Sanchez, M.C., Martínez, J.A., Nortes, P.A., Artes, F. \& Domingo, R. (2007): Effect of deficit irrigation on apricot fruit quality at harvest and during storage. J. Sci. Fd Agric., 87, 2409-2415.

Roussos, P.A., Sefferou, V. Denaxa, N.K., Tsantili, E. \& Stathis, V. (2011): Apricot (Prunus armeniaca L.) fruit quality attributes and phytochemicals under different crop load. Sci. Hort., 129, 472-478.

Ruíz, D. \& EgeA, J. (2008): Phenotypic diversity and relationships of fruit quality traits in apricot (Prunus armeniaca L.) germplasm. Euphytica, 163, 143-158.

Soll Survey Staff (1999): Soil taxonomy. ( $2^{\text {nd }}$ ed.), USDA Ag. HBK. 437, Washington, USA.

Sottile, F., Monte, M. \& Impallari, F. (2006): Vegetative and reproductive behaviour of young apricot trees cv. 'Ninfa' as affected by rootstock. Acta Hort., 717, 79-82.

Tricon, D., Bourguiba, H., Ruiz, D., Blanc, A., Audergon, J.M., Bureau, S., Gouble, B., Grotte, M., Reich, M., Renard, C., Clauzel, G., Brand, R. \& Semon, S. (2009): Evolution of apricot fruit quality attributes in the new released cultivars. Acta Hort., 814, 571-576.

Van Leewen, C., Friant, P., Choné, X., Tregoat, O., Koundouras, S. \& Dubourdieu, D. (2004): Influence of climate, soil and cultivar on terroir. Am. J. Enol. Vitic., 55, 207-217.

Weibel, F.P., Tamm, L., Wyss, E., Daniel, C., Häseli, A. \& Suter, F. (2007): Organic fruit production in Europe: Successes in production and marketing in the last decade, perspectives and challenges for the future development. Acta Hort., 737, 163-172. 